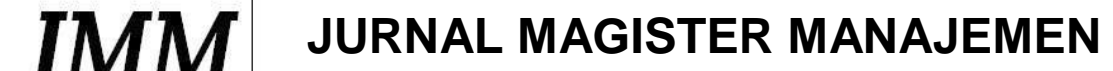 UNIVERSITAS MATARAM

\section{PENGARUH MARKETING PUBLIC RELATIONS TERHADAP BRAND IMAGE DAN LOYALITAS PELANGGANDI STUDIO ALAM TV9 MATARAM}

\author{
Ari Wahyuddin ${ }^{1}$ \\ Handry Sudhiartha Athar ${ }^{2}$
}

\begin{abstract}
This research is aimed at determining and explaining the effect of public relations marketing on the brand image and customers loyalty at Studio Alam TV9. This research is an explanatory research with quantitative approach. This research employed three variables of Public Relations Marketing, Brand Image, and Customers loyalty. The visitors of Studio Alam TV9 that have visited twice or more are the populations of this study. 110 visitors are the respondents of this research selected through purposive random sampling to which the questioners were distributed. The data were analyzed using path analysis. Based on that path analyzed the research showed that public relation marketing has direct and significant effect on Brand Image. And the brand Image has direct and significant effect on the customers loyalty. Beside that it is found that public relation marketing has indirect but significant effect of the customers loyalty through brand image. It is suggested that TV9 maintain and improve the public relation marketing ti improve the brand image and make the customers loyalty.
\end{abstract}

\section{Keywords: Marketing Public Relation, Brand Image, Customer Loyalty}

\section{Pendahuluan}

Era Globalisasi menuntut masyarakat untuk terus bekerja demi memenuhi kebutuhan hidupnya. Kesibukan dengan pekerjaan mengakibatkan para pekerja menjadi jenuh dan membutuhkan refreshing. Kebutuhan akan refreshing ke tempat wisata merupakan hal yang wajib dilakukan untuk menghilangkan kepenatan ditengah kesibukan pekerjaan. Kota Mataram merupakan Ibu Kota Provinsi Nusa Tenggara Barat memiliki berbagai jenis tempat wisata Nasional maupun Internasional yang menjadi tujuan wisata, baik wisatawan mancanegara maupun domestik.

Persaingan tempat tujuan wisata di Kota Mataram disebabkan oleh potensi yang dimiliki Kota Mataram itu sendiri dan juga prospek bisnis di bidang pariwisata tumbuh dengan pesat yang didukung dengan hampir semua masyarakat butuh akan hiburan ke tempat wisata. Hadirnya berbagai macam tempat wisata ini jelas menguntungkan masyarakat selaku konsumen, sebab tersedia banyak macam jenis tempat wisata yang akan dituju. Hal ini tentunya berbanding terbalik dari pandangan perusahaan terkait, sebab dengan hadirnya kompetitor maka secara tidak langsung akan mengancam keberlangsungan perusahaan tersebut. Berbagai macam strategi tentunya sudah disiapkan oleh perusahaan dengan tujuan mempertahankan pelanggan yang sudah ada.

Salah satu tempat wisata yang ramai dikunjungi oleh masyarakat adalah waterpark. Tercatat ada 6 (enam) waterpark di Kota Mataram saat ini. Salah satu waterpark yang

\footnotetext{
${ }^{1}$ Mahasiswa Program Magister Manajemen Pascasarjana Universitas Mataram.

${ }^{2}$ Dosen Pembimbing Pendamping, Dosen Program Magister Manajemen Pascasarjana Universitas Mataram.
} 
cukup dikenal masyarakat Kota Mataram adalah Studio Alam TV9. Jika memperhatikan namanya, tempat wisata ini menganut konsep wisata alam dan dilengkapi dengan stasiun

TV yang senantiasa mengudara. Namun, saat ini Studio Alam TV9 telah dilengkapi dengan waterpark yang menjadi wahana utama pilihan pengunjung.

Studio Alam TV9 dibangun pada tahun 2013 dengan menyiapkan wisata alam berbasis edukasi dan fasilitas outbond yang dilengkapi dengan paint ball. Seiring dengan berjalannya waktu, pada bulan september tahun 2014 Studio Alam TV9 mulai berevolusi menjadi tempat wisata waterpark dengan membangun 4 kolam renang. Wahana waterpark ini dibangun pada lokasiyang menjadi tempat wisata edukasi berupa tanah sawah dan tempat berternak belut. Terpakainya lahan tersebut untuk pembangunan wahana waterpark menyebabkan SATV9 tidak lagi menawarkan wisata edukasi. Perubahan ini menyebabkan pihak perusahaan kembali menawarkan paket baru kepada masyarakat.

Sampai tahun 2016 SATV9 telah membangun 8 (delapan) wahana kolam renang yang berbasis sarana bermain anak-anak. Pembangunan kolam renang ini menyebabkan terjadinya perubahan persepsi (brand image) konsumen yang tadinya SATV9 dikenal sebagai studio alam berbasis edukasi menjadi waterpark. Bahkan pengunjung lebih senang menyebut SATV9 sebagai waterpark TV9.

Tabel 1. Jumlah Pengunjung Studio Alam TV9

\begin{tabular}{|c|c|c|c|c|c|}
\hline \multirow{2}{*}{ NO. } & \multirow{2}{*}{ BULAN } & \multicolumn{4}{|c|}{ TAHUN } \\
\hline & & 2013 & 2014 & 2015 & 2016 \\
\hline 1. & Januari & - & 170 & 7.668 & 14.482 \\
\hline 2. & Februari & - & 231 & 4.088 & 5.767 \\
\hline 3. & Maret & - & 456 & 3.593 & 6.867 \\
\hline 4. & April & - & 603 & 3.605 & 5.823 \\
\hline 5. & Mei & - & 579 & 6.809 & 28.202 \\
\hline 6. & Juni & - & 2.193 & 14.219 & 10.595 \\
\hline 7. & Juli & - & 532 & 7.648 & 11.476 \\
\hline 8. & Agustus & - & 1.346 & 2.951 & 1.868 \\
\hline 9. & September & 264 & 764 & 4.863 & - \\
\hline 10. & Oktober & 498 & 810 & 4.164 & - \\
\hline 11. & November & 612 & 1.292 & 5.905 & - \\
\hline 12. & Desember & 2.046 & 4.715 & 17.972 & - \\
\hline
\end{tabular}




\section{IMM JURNAL MAGISTER MANAJEMEN UNIVERSITAS MATARAM UNRAM VOL. 6 No. 1 MARET 2017}

\begin{tabular}{|l|l|l|l|l|l|}
\hline & Jumlah & 3.420 & 13.691 & 83.485 & 85.080 \\
\hline
\end{tabular}

Sumber: Studio Alam TV 9

Berdasarkan tabel di atas dapat dilihat bahwa semakin lama pengunjung Studio Alam TV9 mengalami peningkatan. Peningkatan pengunjung bisa dilihat pada bulan-bulan liburan anak sekolah. Pembangunan kolam tambahan berdampak langsung pada jumlah pengunjung. Apalagi bisa dilihat jumlah pengunjung pada tahun 2016 sampai bulan Agustus telah melampaui capaian tahun sebelumnya. Pertumbuhan jumlah pengunjung inilah yang menjadi alasan peneliti memilih Studio Alam TV9 sebagai objek penelitian dengan meneliti pengaruh strategi marketing public relations terhadap brand image dan loyalitas pelanggan Studio Alam TV9.

Marketing Public Relations adalah suatu proses pemasaran yang dilakukan melalui komunikasi yang baik mengenai informasi dari perusahaan terhadap citra merek (brand image) pada suatu produk tertentu (Thomas M.Harris dalam Soemirat dan Ardianto 2008:154). Strategi diterapkan dibawah kontrol General Manager Studio Alam TV9 itu sendiri yang melakukan kerjasama dengan PT. Progres sebagai mitra marketing perusahaan yang baru terlaksana pada tahun 2015.

Pesan yang dikomunikasikan oleh Marketing Public Relations dalam upaya promosi sifatnya informative, mendalam, menimbulkan pemahaman dari konsumen serta memiliki kredibilitas sehingga akan lebih dipercaya oleh khalayak sebanding iklan (Abadi,1994). Strategi ini telah diterapkan pihak perusahaan dengan cara door to doorke beberapa sekolah, kantor dan beberapa tempat lainnya dengan menawarkan paket wisata alam yang telah disiapkan. Selain itu, publikasi, event, sponsorship dan pemasangan iklan melalui media cetak, radio dan televisi telah dilakukan Studio Alam TV9 untuk meningkatkan pengunjung.

Loyalitas pelanggan merupakan tujuan akhir dari perusahaan, terutama bagi Studio Alam TV9. Mempertahankan pelanggan jauh lebih efektif dan efisien daripada harus mencari pelanggan yang baru.Dibutuhkan biaya yang mahal untuk mendapatkan pelanggan, apalagi mengingat iklim kompetisi pasar yang semakin ketat. Keuntungan yang didapat dari loyalitas pelanggan yaitu meminimalisir pengaruh serangan dari para kompetitor perusahaan sejenis. Persaingan antar perusahaan sejenis tak hanya dalam hal produk yang dihasilkan tetapi juga persepsi (citra) masyarakat yang berpengaruh terhadap loyalitas pelanggan.

Seperti dijelaskan sebelumnya, marketing public relationsmelakukan proses pemasaran dengan mengkomunikasikan citra merek (brand image) suatu produk tertentu kepada pelanggan. Hal ini sejalan dengan hasil penelitian Hadyan et.al (2015), menyatakan bahwa dalam mempertahankan citra dapat dilakukan dengan strategi marketing public relation.

Marketing Public Relations jika dilakukan dengan tepat, maka akan menciptakan sebuah keloyalan konsumen dengan produk yang ditawarkan perusahaan (Juliansyah, 2008:12). Hidayat (2015), menyatakan bahwa loyalitas pelanggan dipengaruhi oleh peranan Marketing Public Relation. Selain itu, Nur (2013), menyatakan bahwa public relations berpengaruh terhadap loyalitas pelanggan. Namun hal ini tidak sejalan dengan penelitian yang dilakukan Rehulina et.al (2015), menyatakan bahwa marketing publicrelationsmemiliki pengaruh yangtidaksignifikan terhadap loyalitas pelanggan. Hidayat (2015), menyatakan bahwa loyalitas pelanggan selain dipengaruhi oleh peranan Marketing Public Relation, juga 


\section{IMM JURNAL MAGISTER MANAJEMEN UNIVERSITAS MATARAM UNRAM VOL. 6 No. 1 MARET 2017}

dipengaruhi oleh faktor-faktor lain diluar penelitian tersebut. Faktor lain inilah yang akan coba diteliti dengan menambahkan variabel brand image untuk meneliti pengaruhnya

terhadap loyalitas pelanggan. Selain itu, peneliti belum menemukan penelitian yang menggunakan 3 (tiga) variabel yaitu, marketing public relations, brand image dan loyalitas pelanggan secara bersamaan dengan mengambil objek penelitian tempat wisata khususnya waterpark.

Fenomena inilah yang menarik perhatian peneliti untuk melakukan penelitian yang dalam studi ini berjudul"Pengaruh Marketing Public Relations Terhadap Brand Image Dan Loyalitas Pelanggan Di Studio Alam TV9 Mataram".

\subsection{Marketing PublicRelations}

\section{KAJIAN PUSTAKA}

Menurut Kotler dan Amstrong (2008, p.6) pemasaran adalah suatu proses sosial dan manajerial di mana pribadi atau organisasi memperoleh yang mereka butuhkan dan inginkan melalui penciptaan dan pertukaran nilai dengan yang lain. Dengan demikian dapat disimpulkan bahwa pemasaran merupakan kegiatan yang dilakukan oleh individu ataupun organisasi yang mencakup proses perencanaan, harga, promosi dan distribusi terhadap suatu ide, barang atau jasa untuk menciptakan pertukaran yang memuaskan.

Menurut Kotler dan Keller (2008, p.276-277), perusahaan tidak hanya harus berhubungan secara konstruktif dengan pelanggan, pemasok dan penyalur. Melainkan juga harus berhubungan dengan sejumlah besar masyarakat yang berkepentingan. Masyarakat (public) adalah setiap kelompok yang memiliki kepentingan atau pengaruh terhadap kemampuan suatu perusahaan dalam mencapai tujuan saat ini atau pada masa mendatang. Hubungan masyarakat (public relations) meliputi berbagai program yang dirancang untuk mempromosikan atau melindungi citra perusahaan atau masing-masing produknya.

Menurut Kotler dan Keller (2008, p.279), Alat-alat utama Marketing Public Relationsyang akan menjadi indikator dalam penelitian iniantara lain:

1) Terbitan: Perusahaan sangat mengandalkan bahan-bahan yang diterbitkan untuk menjangkau dan mempengaruhi pasar sasarannya. Bahan-bahan ini mencakup: brosur, artikel, berita berkala dan majalah perusahaan, laporan tahunan, dan audiovisual.

2) Acara-acara: Perusahaan dapat menarik perhatian pada produk-produk baru atau kegiatan-kegiatan perusahaan lainnya dengan menyelenggarakan acara khusus seperti konferensi berita, seminar, tamasya, pameran dagang, pemajangan produk, kontes dankompetisi.

3) Pemberian dana sponsor: Perusahaan dapat mempromosikan mereka dan nama perusahaannya dengan mensponsori pertandingan olahraga dan acara budaya dan tujuan-tujuan yang sangat dihargai.

4) Berita: Salah satu tugas utama profesional humas adalah menemukan atau menciptakan berita yang menguntungkan tentang perusahaan tersebut, produknya dan orang-orangnya, dan mengupayakan agar media menerima siaran pers dan menghadiri konferensipers.

5) Ceramah: Makin banyak eksekutif perusahaan harus menjawab dengan tangkas pertanyaan-pertanyaan dari media atau member ceramah dalam perhimpunanperhimpunan perdagangan atau rapat-rapat penjualan, dan penampilan ini dapat 


\section{IMM JURNAL MAGISTER MANAJEMEN UNIVERSITAS MATARAM UNRAM \\ VOL. 6 No. 1 MARET 2017}

membangun citra perusahaantersebut.

6) Kegiatan Layanan Masyarakat: Perusahaan dapat membangun kehendak baik dengan menyumbangkan uang dan waktu untuk tujuan-tujuan yangbaik.

7) Media Identitas: Perusahaan membutuhkan identitas visual yang langsung dikenal masyarakat. Identitas visual tersebut terdapat dalam logo perusahaan, alat tulis, brosur, tanda, formulir bisnis, kartu nama, bangunan, seragam dan aturanberpakaian.

\subsection{Brand Image (Citra Merek)}

Sebelum menjelaskan pengertian brand image, maka terlebih dahulu akan dijelaskan arti brand (merek). Menurut (Kotler 1994), "A brand is name, term, sign, symbol, or design, or acombination of them, intended to identify the goods or service of one seller or groupof sellers and to differentiate them from those of competitor." Maksudnya, merek adalah nama, istilah, tanda, symbol, atau desaign atau kombinasi dari semuanya itu yang dimaksudkan untuk mengidentifikasi barang atau jasa dari seseorang atau sekelompok penjual untuk untuk membedakannya dari produk atau barang pesaing.

Brand Image adalah representasi dari keseluruhan persepsi terhadap merek dan dibentuk dari informasi dan pengalaman masa lalu terhadap merek itu. Citra terhadap merek berhubungan dengan sikap yang berupa keyakinan dan preferensi terhadap suatu merek. Konsumen yang memiliki citra yang positif terhadap suatu merek, akan lebih memungkinkan untuk melakukan pembelian (Setiadi, 2003).

Dijelaskan dalam bukunya Kottler mendefinisikan brand image sebagai seperangkat keyakinan, ide dan kesan yang dimiliki seorang terhadap suatu merek. Karena itu sikap dan tindakan konsumen terhadap suatu merek sangat di tentukan oleh brand image merupakan syarat dari merek yangkuat.

Menurut Shiffman dan kanuk(1997), menyebutkan faktor-faktor pembentuk brand image adalah sebagai berikut:

a. Kualitas atau mutu, berkaitan dengan kualitas produk yang ditawarkan oleh produsen dengan merektertentu.

b. Dapat dipercaya atau diandalkan, berkaitan dengan pendapat dan kesepakatan yang dibentuk oleh masyarakat tentang suatu produk yang dikonsumsi.

c. Kegunaan atau manfaat, berkaitan dengan fungsi dari suatu produk yang dimanfaatkan olehkonsumen.

d. Pelayanan, berkaitan dangan tugas produsen dalam melayani konsumennya.

e. Resiko, berkaitan dengan untung rugi yang dialami olehkonsumen.

f. Harga, dalam hal ini berkaitan dengan tinggi rendahnya atau banyak sedikitnya jumlah uang yang dikeluarkan konsumen untuk mempengaruhi suatu produk, juga dapat mempengaruhi citra jangka panjang.

g. Image, yang dimiliki merek itu sendiri, yaitu berupa pelanggan, kesempatan dan informasi yang berkaitan dengan suatu merek dari produktertentu.

Menurut Timmerman (dalam Noble, 1999) brand image sering terkonseptualisasi sebagai sebuah koleksi dari semua asosiasi yang berhubungan dengan sebuah merek. Citra merek terdiri dari:

a. Faktor fisik: karakteristik dari merek tersebut, seperti desain kemasan, logo, nama merek, fungsi dan kegunaan produk dari merekitu.

b. Faktor psikologis: dibentuk oleh emosi, kepercayaan, nilai, kepribadian yang dianggap oleh konsumen menggambarkan produk dari merek tersebut. 


\section{IMM JURNAL MAGISTER MANAJEMEN UNIVERSITAS MATARAM

Berdasarkan uraian di atas dapat disimpulkan bahwa faktor-faktor pembentuk brand image yaitu faktor fisik (kemasan, logo, nama merek) dan faktor psikologis (kepercayaan, nilai, kepribadian), kualitas atau mutu, dapat dipercaya, manfaat dan harga. Brand image sangat erat kaitananya dengan apa yang orang pikirkan, rasakan terhadap suatu merek tertentu sehingga dalam citra merek faktor psikologis lebih banyak berperan dibandingkan faktor fisik dari merektersebut.

Menurut Biels dalam Consugno (2006:137) mengatakan bahwa Citra merek dapat diukur dengan 3 bagian, yaitu :

1. Citra produsen (production image) yaitu sekumpulan asosiasi yang dipersepsikan konsumen terhadap perusahaan yang membuat suatu barang/jasa. Bagi produsen, manfaat brand adalah :

a. Brand memudahkan penjual mengolah pesanan dan menelusuri masalah-masalah yang timbul.

b. Brand memberikan perlindungan hukum atas keistimewaan atau ciri khas produk.

c. Brand memungkinkan untuk menarik sekelompok pembeli yang setia dan menguntungkan.

d. Brand membantu penjual melakukan segmentasi pasar.

2. Citra Konsumen (Customer image) yaitu sekumpulan asosiasi yang dipersepsikan oleh konsumen terhadap pemakai yang menggunakan suatu barang/jasa. Bagi konsumen, manfaat brand adalah brand dapat menceritakan sesuatu kepada pembeli tentang mutu. Brand membantu menarik perhatian pembeli terhadap produk-produk baru yang mungkin bermanfaat bagi mereka.

3. Citra produk (produk image) yaitu sekumpulan asosiasi yang dipersepsikan konsumen terhadap suatu barang/jasa.
a. Professional.
b. Kualitas produk asli atau palsu.
c. Berkualitas baik.
d. Desain menarik.
e. Bermanfaat bagi konsumen.

\subsection{LoyalitasPelanggan}

Loyalitas menurut Mowen dan Minor (dalam Supriyono, 2007) adalah kondisi dimana pelanggan mempunyai sikap yang positif terhadap suatumerek, mempunyai

komitmen terhadap merek tersebut dan bermaksud meneruskan pembeliannya dimasa mendatang.

Loyalitas konsumen menurut Arnould (dalam Sulistiadi,2010) adalah komitmen pelanggan bertahan secara mendalam untuk berlangganan kembali atau melakukan pembelian ulang produk atau jasa terpilih secara konsisten dimasa yang akan datang, meskipun pengaruh situasi dan usaha-usaha pemasaran mempunyai potensi penyebabkan perubahan perilaku.

Sedangkan seorang pelanggan yang loyal menurut (Griffin, 1993) adalah “A customer is loyal if she or he exhibit purchase defined as nonrandom purchased overtime by some decisionmaking unit, in addition, the term loyaly is a concondition and requires that the act of purchase occurs no less than two times". Artinya bahwa seorang pelanggan dapat dikatakan 


\section{IMM JURNAL MAGISTER MANAJEMEN UNIVERSITAS MATARAM

setia atau loyal apabila pelanggan tersebut menunjukkan pembelian secara teratur atau terdapat suatu kondisi dimana mewajibkan pelanggan membeli paling sedikit dua kali dalam selang waktu tertentu.

Dari beberapa teori yang dikemukakan para ahli diatas dapat disimpulkan bahwa Loyalitas pelanggan adalah kesetiaan pelanggan atau komitmen pelanggan untuk berlangganan atau melakukan pembelian ulangminimal dua kali terhadap suatu merek secara konsisten dimasa yang akan datang.

Setelah mengetahui dan memahami penjelasan atas definisi loyalitas pelanggan dan maka perlu untuk memahami faktor-faktor yang mempengaruhi loyalitas pelanggan menurut (Tjiptono, 2005) adalah (a) kepuasan, (b) kualitas produk, (c) citra merek. Sedangkan menurut Marconi (dalam Ratri, 1994) keputusan pelanggan untuk tetap loyal didasarkan pada pertimbangan-pertimbangan nilai, reputasi dan karakteristik merek, kenyamanan dan kemudahan dalam mendapatkan merek dan pelayanan. Menurut Loudon dan Bitta (dalam lutitary 2008) secara umum loyalitas dapat dipengaruhi oleh berbagai faktor diantaranya usia dan tingkat pendidikan.

Menurut Griffin (dalam Huriyati, 2002),pelanggan yang loyal memiliki ciri-ciri sebagai berikut:

a. Makes regular repeatpurchase

Menunjukkan bahwa pelanggan yang setia adalah pelanggan yang melakukan pembelian ulang secara teratur terhadap produk barang dan jasa.

b. Purchases acroos produk and sevicelines

Dimana pelanggan yang setia tidak hanya membeli satu macam produk atau variant baru apabila perusahaan tersebut mengeluarkan produk baru, maka pelanggan yang setia akan membeli produk tersebut atau membeli antar lini produk atau jasa.

c. Refer toother

Merekomendasikan produk atau jasa kepada orang lain.

d. Demonstrate the degree of immunity to the full ofcompettion

Dimana pelanggan yang setia akan menunjukkan kekebalan dari daya tarik produk sejenis dari pesaing.

Berdasarkan uraian di atas dapat dirumuskan bahwa ciri-ciri Pelanggan yang loyal adalah melakukan pembelian ulang danteratur,membeli antar lini produk atau jasa, merekomendasikan kepada orang lain, menunjukkan kekebalan terhadap tarikan pesaing. Peneliti memilih teori di atas sebagai indikator penelitian karena dianggap bisa mewakili penjelasan teori sebelumnya tentang loyalitas pelanggan dan dianggap lebih lengkap untuk menyusun kuisioner.

\subsection{Kerangka Konseptual}

Kerangka konseptual dari penelitian ini digambarkan sebagai berikut: 


\section{TMM JURNAL MAGISTER MANAJEMEN UNIVERSITAS MATARAM

Gambar 1. Kerangka Konseptual

H3

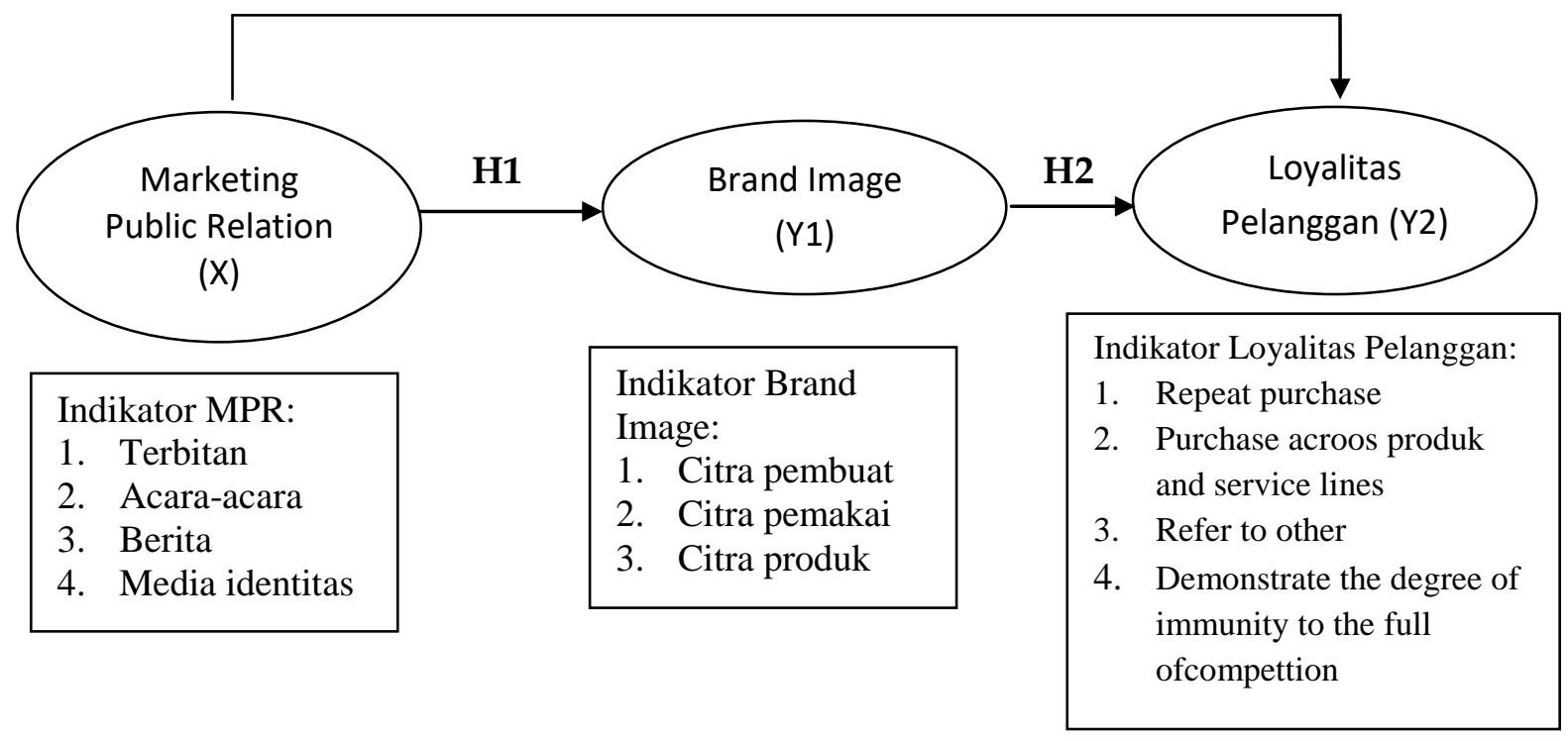

3. METODOLOGI PENELITIAN

Penelitian ini merupakan penelitian eksplanatori (explanatory research) dengan pendekatan kuantitatif. Menurut Umar (1999:36) penelitian eksplanatori (explanatory research) adalah penelitian yang bertujuan untuk menganalisis hubungan-hubungan antara satu variabel dengan variabel lainnya atau bagaimana suatu variabel mempengaruhi variabel lainnya. Metode kuantitatif adalah pendekatan ilmiah terhadap pengambilan keputusan manajerial dan ekonomi (mudrajad 2007:1). Pendekatan ini berangkat dari data yang diibaratkan bahan baku dalam suatu pabrik, data ini diproses dan dimanipulasi menjadi informasi berharga bagi pengambilan keputusan.

Populasi yang digunakan dalam penelitian ini adalah pengunjungStudio Alam TV9. Pengambilan sampel dilakukan secara purposive sampling. Purposive sampling adalah pemilihan sampel berdasarkan karakteristik tertentu yang dianggap mempunyai sangkut pautnya dengan karakteristik populasi yang sudah diketahui sebelumnya (Rosady, 2010:157). Karakteristik sampel dalam penelitian ini adalah pengunjung yang telah melakukan kunjungan minimal 2 kali dengan umur di atas 15 tahun dan pendidikan terakhir minimal SMP.

Keterwakilan populasi oleh sampel dalam penelitian merupakan syarat penting untuk melakuakan generalisasi. Ferdinand (2002:51) menyatakan bahwa bila ukuran sampel terlalu besar maka model menjadi sangat sensitive sehingga sulit untuk mendapatkan goodness of fityang baik. Untuk itu disarankan ukuran sampel adalah 5-10 kali jumlah variabel manifest (indikator) dari keseluruhan variabel laten (Solimun, 2002:83). Karena dalam penelitian ini jumlah indikator seluruhnya adalah 11 maka jumlah sampel yang digunakan dalam penelitian ini adalah $11 \times 10=110$.

Teknik analisis jalur (path analysis) digunakan untuk menganalisis pola hubungan antar variabel dengan tujuan untuk mengetahui pengaruh langsung dan tidak langsung seperangkat variabel bebas/eksogen terhadap varibel terikat/endogen (Riduwan dan Engkos, 2014:2). Dalam penelitian ini, analisis jalur digunakan dalam menguji besarnya 


\section{IMM JURNAL MAGISTER MANAJEMEN UNIVERSITAS MATARAM

kontribusi yang ditunjukkan oleh koefisien jalur dari hubungan kausal antar variabel Marketing Public Relations $(X)$ terhadap Brand Image $\left(\mathrm{Y}_{1}\right)$ dan Loyalitas Pelanggan $\left(\mathrm{Y}_{2}\right)$. Kemudahan dalam perhitungan, menggunakan AMOS Windows Version 21. Adapun langkah-langkah analisis jalur sebagai berikut :

1) Langkah pertama adalah membuat model dan rancangan penelitian.

Kerangka hubungan kausal empiris antara jalur dapat dibuat melalui persamaan struktur sebagai berikut.

$€_{1}$

$€_{2}$

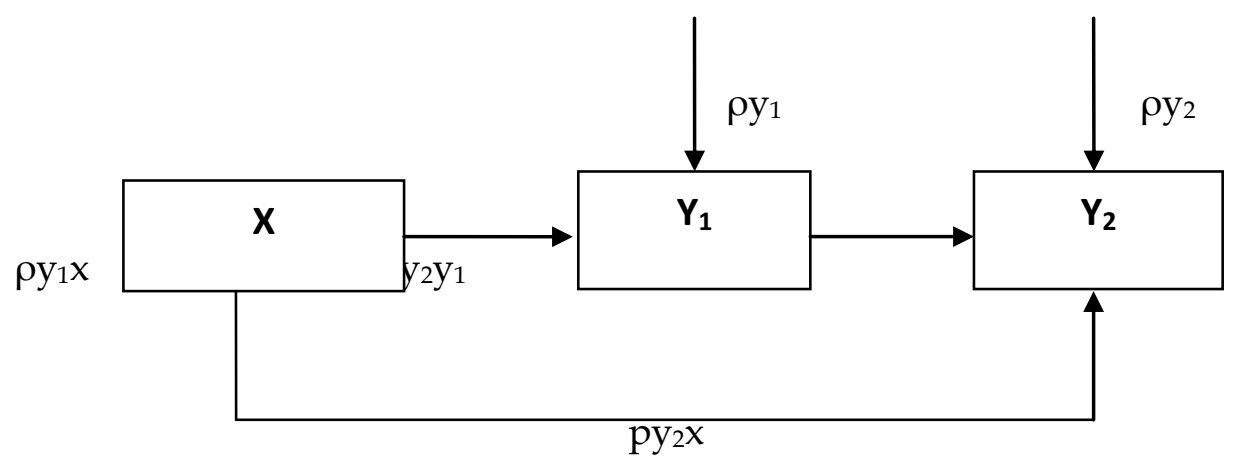

Gambar 2.Hubungan Struktur Kausal X dan Y1 terhadap Y2

Sumber: Riduwan $(2007 ; 116)$ dan diolah

Persamaan strukturalnya sbb :

$$
\begin{aligned}
& \text { Struktur I : } Y_{1}=\rho y_{1} x X+\rho y_{1} \varepsilon_{1} \\
& \text { Struktur II : } Y 2=\rho y_{2} y_{1} Y_{1}+\rho y_{2} x Y_{2}+\rho y_{2} \varepsilon_{2}
\end{aligned}
$$

2) Menghitung koefisien jalur secara simultan (keseluruhan).

Hipotesis statistik dirumuskan sebagai berikut :

Ha : $\rho y 1 x=\rho y 2 y 1 \neq 0$

Ho: $\rho y 1 x=\rho y 2 y 1=0$

Kaidah pengujian signifikan : Program SPSS

- Jika nilai probabilitas 0,05 lebih kecil atau sama dengan nilai probabilitas Sig atau $(0,05 \leq \mathrm{Sig})$, maka Ho diterima dan Ha ditolak, artinya tidak signifikan.

- Jika nilai probabilitas 0,05 lebih besar atau sama dengan nilai probabilitas Sig atau $(0,05 \geq \mathrm{Sig})$, maka Ho ditolak dan Ha diterima, artinya signifikan.

- Apabila dari tabel Anova diperoleh nilai F dengan nilai probabolitas (sig) <0,05, yang artinya Ho ditolak dan Ha diterima, maka pengujian secara individual dapat dilakukan.

3) Menghitung secara individual.

Dengan menggunakan AMOS Windows Version 21, dari Tabel Coeficients akan didapat nilai signifikan dari variabel. Selanjutnya untuk mengetahui signifikan analisis jalur bandingkan antara nilai probabilitas 0,05 dengan nilai probabilitas Sig dengan dasar pengambilan keputusan sebagai berikut :

1) Jika nilai probabilitas 0,05 lebih kecil atau sama dengan nilai probabilitas Sig atau $[0,05 \leq$ Sig $]$, maka Ho diterima dan Ha ditolak, artinya tidak signifikan. 


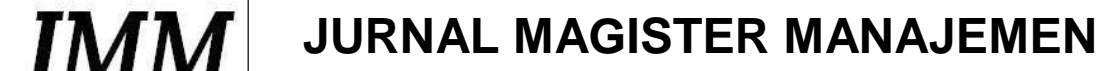 UNIVERSITAS MATARAM

2) Jika nilai probabilitas 0,05 lebih besar atau sama dengan nilai probabilitas Sig atau $[0,05 \geq$ Sig $]$, maka Ho ditolak dan Ha diterima, artinya signifikan.

4) Memaknai hasil Path Analysis.

a. Menghitung hasil kontrubusi masing-masing model.

b. Menghitung pengaruh langsung, tidak langsung dan pengaruh total.

\section{HASIL PENELITIAN}

4.1 Deskripsi Variabel Penelitian

1) Marketing Public Relation

Marketing Public Relation di Studio Alam TV9 merupakanpersepsi responden terhadap perpaduan antara program strategi pemasaran dengan program public relations yang dilakukan Studio Alam TV9 dengan tujuan memuaskan pengunjung. Pernyataan yang diajukan untuk variabel ini sebanyak 10 item pernyataan.Umumnya responden memiliki tanggapan dengan kategori baik dan sangat baik. Sementara ratarata total dari Marketing Public Relation dari tanggapan responden sebesar4,02dengan kriteria baik, artinya Marketing Public Relation di Studio Alam TV9 sudah dilaksanakan dengan baik.

\section{2) Brand Image}

Brand Imagemerupakanpersepsi serta keyakinan responden terhadap nilai, kualitas atau mutu Studio Alam TV9. Pernyataan yang diajukan untuk variabel ini sebanyak 10 item pernyataan. Umumnya responden memiliki tanggapan dengan kategori tinggi dan sangat tinggi. Sementara rata-rata total dariBrand Image dari tanggapan responden sebesar 4,22dengan kriteria sangat Tinggi. Hal ini bermakna bahwa pengunjung memiliki keyakinan responden terhadap nilai, kualitas atau mutu Studio Alam TV9 sangat tinggi.

\section{3) Loyalitas Pelanggan}

Loyalitas Pelangganmerupakanpersepsi responden terhadap komitmen yang dipegang oleh pengunjung Studio Alam TV9 untuk berkunjung kembali meski adanya alternative tempat wisata sejenis lainnya. Pernyataan yang diajukan untuk variabel ini sebanyak 7 item pernyataan. Umumnya responden memiliki tanggaan dengan kategori tinggi dan sangat tinggi. Sementara rata-rata total dari Loyalitas Pelangganberdasarkan tanggapan responden sebesar 4,09dengan kriteriatinggi.Kriteria ini menunjukkan bahwa komitmen yang dipegang oleh pengunjung sangat tinggi untuk berkunjung kembali ke Studio Alam TV9.

\subsection{Hasil Analisis Jalur}

Berdasarkan analisis hasil yang dilakukan dengan menggunakan analisis jalur, maka dapat dihitung pengaruh variabel eksogen terhadap variabel endogen. Pengaruh tersebut berupa pengaruh signifikan, pengaruh tidak signifikan. Analisis mengenai signifikansi koefisien jalur dianalisis melalui signifikansi besaran regression weights menunjukkan bahwa terdapat pengaruh yang signifikan antara variabel $\mathrm{X}$ terhadap $\mathrm{Y} 1$ maupun $\mathrm{Y} 2$ karena nilai critical rasio (CR) lebih besar dari 2 atau $p \leq 0,05$. Adapun hasil analisis tersebut selengkapnya dapat dilihat pada tabel berikut : 


\section{TMM JURNAL MAGISTER MANAJEMEN UNIVERSITAS MATARAM UNRAM VOL. 6 No. 1 MARET 2017}

Tabel 2.Regression Weights

\begin{tabular}{|l|c|l|c|c|c|c|}
\hline & & & Koefisien & S.E. & C.R. & Sig. \\
\hline $\begin{array}{l}\text { Brand Image } \\
\left(Y_{1}\right)\end{array}$ & $<---$ & $\begin{array}{l}\text { Marketing Public } \\
\text { Relation }(X)\end{array}$ & 0,604 & 0,079 & 7,692 & $* * *$ \\
\hline $\begin{array}{l}\text { Loyalitas } \\
\text { Pelanggan }\left(\mathrm{Y}_{2}\right)\end{array}$ & $<---$ & $\begin{array}{l}\text { Marketing Public } \\
\text { Relation }(X)\end{array}$ & 0,414 & 0,101 & 4,121 & $* * *$ \\
\hline $\begin{array}{l}\text { Loyalitas } \\
\text { Pelanggan }\left(\mathrm{Y}_{2}\right)\end{array}$ & $<---$ & Brand Image $\left(Y_{1}\right)$ & 0,441 & 0,099 & 4,467 & $* * *$ \\
\hline
\end{tabular}

Berdasarkan hasil pengujian seperti yang disajikan pada tabel 4.13., secara grafik jalur yang signifikan dan tidak signifikan dapat dilihat pada gambar 4.1. di bawah ini.

\section{Gambar 3. Gambar Analisis Jalur}

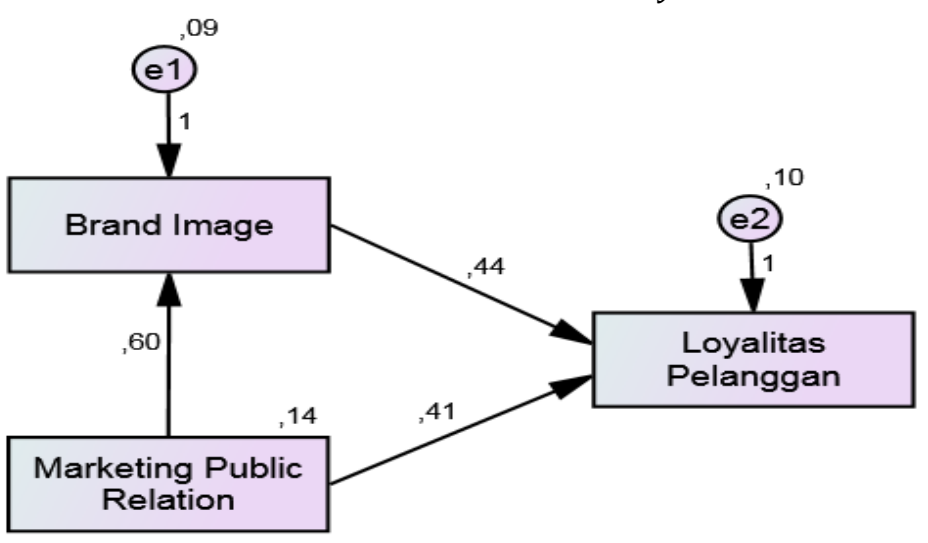

Keterangan :

Jalur $X \rightarrow$ Y1 signifikan

Jalur $X \rightarrow Y 2$ signifikan

Jalur Y1 $\rightarrow$ Y2 signifikan

\subsection{Pembuktian Hipotesis}

Dengan menggunakan hasil analisis jalur, pada tingkat signifikansi sebesar 0,05 maka dapat dilakukan pembuktian perumusan hipotesa. Hasil uji hipotesa dapat dilihat pada tabel berikut ini :

\section{1) Hasil Pengujian Hipotesis 1}

Hipotesis Pertama (H1) dalam Penelitian ini menyatakan "Semakin baik Marketing Public Relations,semakin baik Brand Image Studio Alam TV9". Pembuktian hipotesis ini dilakukan dengan analisis jalur yang menunjukkan bahwa besarnya pengaruh dari Marketing Public Relationterhadap Brand Image sebesar 0,604 pada taraf signifikansi 0,000 dengan taraf kesalahan pada Kategori 5\% (0,05). Taraf signifikansi

untuk pengaruh antar variabel sebesar 0,000 dimana nilai ini lebih kecil dari standar toleransi kesalahan sebesar 5\% $(0,05)$ yang berarti signifikan. Dengan demikian, dapat disimpulkan bahwa terdapat pengaruh yang signifikan dari Marketing Public Relation terhadap Brand Image sehingga hipotesis pertama diterima.

2) Hasil Pengujian Hipotesis 2 


\section{IMM JURNAL MAGISTER MANAJEMEN UNIVERSITAS MATARAM

Hipotesis kedua $\left(\mathrm{H}_{2}\right)$ dalam Penelitian ini menyatakan "Semakin baikBrand Image, semakin baikLoyalitas Pelanggan Studio Alam TV9". Pembuktian hipotesis ini dilakukan dengan analisis jalur yang menunjukkan bahwa besarnya pengaruh dariBrand Imageterhadap Loyalitas Pelanggansebesar 0,441 pada taraf signifikansi 0,000 dengan taraf kesalahan pada Kategori 5\% $(0,05)$. Taraf signifikansi untuk pengaruh antar variabel sebesar 0,000 dimana nilai ini lebih kecil dari standar toleransi kesalahan sebesar 5\% $(0,05)$ yang berarti signifikan. Dengan demikian, dapat disimpulkan bahwa terdapat pengaruh yang signifikan dari Brand Image terhadap Loyalitas Pelanggan sehingga hipotesis kedua diterima.

3) Hasil Pengujian Hipotesis 3

Hipotesis ketiga (H3) dalam Penelitian ini menyatakan "Semakin baikMarketing Public Relations, semakin baikLoyalitas Pelanggan Studio Alam TV9". Pembuktian hipotesis ini dilakukan dengan analisis jalur yang menunjukkan bahwa besarnya pengaruh dari Marketing Public Relationterhadap Loyalitas Pelanggansebesar 0,414 pada taraf signifikansi 0,000dengan taraf kesalahan pada Kategori 5\% (0,05). Taraf signifikansi untuk pengaruh antar variabel sebesar 0,000dimana nilai ini lebih kecil dari standar toleransi kesalahan sebesar $5 \%(0,05)$ yang berarti signifikan. Dengan demikian, dapat disimpulkan bahwa terdapat pengaruh yang signifikan dari Marketing Public Relationterhadap Loyalitas Pelanggansehingga hipotesis ketigaditerima.

\subsection{Pembahasan}

\subsubsection{Pengaruh Marketing Public RelationTerhadap Brand Image}

Hasil penelitian menunjukkan Marketing Public Relation berpengaruh positif dan signifikan terhadap Brand Image. Hal ini menunjukkan bahwa semakin baik Marketing Public Relation, semakin baikBrand Image Studio Alam TV9 sehingga hipotesa pertama dapat diterima.Menurut Thomas L. Harris, pencetus pertama konsep Marketing Public Relations dalam bukunya berjudul The Marketer's Guide to Public Relations dengan konsepsinya sebagai berikut: "Marketing Public Relations is the process of planning and evaluating programs, that encourage purchase and customer through credible communication of information and impression that identify companies and their products with the needs, concern of customer".

Marketing Public Relations (MPR) merupakan proses perencanaan dan pengevaluasian program-program yang merangsang pembelian dan kepuasan konsumen melalui komunikasi mengenai informasi yang dapat dipercaya dan melalui kesan-kesan yang menghubungkan perusahaan dan produknya sesuai dengan kebutuhan, keinginan, perhatian dan kepentingan para konsumen (Ruslan,2002:p.253).

Marketing Public Relations sebagai suatu proses perencanaan, pelakasanaan dan pengevaluasian program-program yang memungkinkan terjadinya pembelian dan pemuasan konsumen melalui komunikasi yang baik mengenai informasi dari perusahaan terhadap citra merek (Brand Image)terhadap suatu produk tertentu (Sakaabadi,1994:p.46). Definisi menurut Kotler mengatakan bahwa : "Marketing Public Relations works because works it adds value to product through it's unique ability to lend credibility to product message". Marketing Public Relations diciptakan untuk menambah atau memberikan nilai bagi produk melalui kemampuan yang unik untuk menunjukkan kredibilitas pesan produk (Ruslan, 2002, p.254).

Menurut Ardianto (2009, p.121) Marketing Public Relations ini adalah konsep Public Relations yang berorientasi pemasaran. Sebelum dan sesudah marketing 


\section{TMM JURNAL MAGISTER MANAJEMEN UNIVERSITAS MATARAM

dijalankan, maka perlu diakses dahulu atau dipelihara oleh Public Relations dengan melakukan pembentukan citra (image building) suatu produk atau jasa yang positif. Bila citra perusahaan, produk atau jasa sudah positif di mata konsumen, maka mempermudah upaya pemasaran publik untuk menjadi pelanggan.

Menurut Soemirat dan Ardianto (2008:154), menyatakan bahwa sasaran dari Marketing Public Relations adalah untuk memantapkan imageyang positif bagi produk dan usaha sebuah perusahaan. Ruslan (2001:246) juga berpendapat bahwa tujuan dari Marketing Public Relations yaitu untuk menumbuhkan citra positif publik eksternal atau masyarakat dan konsumen. Sejalan dengan penelitian yang dilakukan oleh Sinaga (2010), yang menunjukkan bahwa marketingpublicrelationsmemilikipengaruhyang positif dan signifikan dalam meningkatkan Brand Image kepada pelanggan. Hasil penelitian ini juga sejalan dengan penelitian yang dilakukan olehHadyan et.al (2015), menyatakan bahwa dalam mempertahankan citra dapat dilakukan dengan strategi Marketing Public Relations.

\subsubsection{Pengaruh Brand Image Terhadap Loyalitas Pelanggan}

Hasil penelitian menunjukkan Brand Image berpengaruh positif dan signifikan terhadap Loyalitas Pelanggan. Hal ini menunjukkan bahwa semakin baik Brand Image, semakin baik Loyalitas Pelanggan Studio Alam TV9 sehingga hipotesa kedua dapat diterima.Hubungan antara citra merek dengan loyalitas konsumen terletak pada keinginan-keinginan dan pilihan konsumen (preference) atas suatu merek merupakan sikap konsumen. Dalam banyak hal, sikap terhadap merek tertentu sering mempengaruhi apakah konsumen akan loyal atau tidak. Persepsi yang baik dan kepercayaan konsumen terhadap suatu merek tertentu akan menciptakan minat beli konsumen dan bahkan meningkatkan loyalitas konsumen terhadap produk tertentu. Teori penghubung antara citra merek dengan loyalitas konsumen dikutip dari Rangkuti (2002)yangmengatakan bahwa Apabila konsumen beranggapan bahwa merek tertentu secara fisik berbeda dari merek pesaing, citra merek tersebut akan melekat secara terus menerus sehingga dapat membentuk kesetiaan terhadap merek tertentu yang disebut dengan loyalitas merek.

Menurut Keller dalam Tjiptono (2005:20), menyatakan bahwabrand image dapat menciptakan pelanggan yang loyal. Hasil penelitian tersebut sejalan denganpenelitian yang dilakukan oleh Vellayati (2014), yaitu citra perusahaan berpengaruh signifikan terhadap loyalitaspelanggan.Gronroos dalam Sutisna (2001:332-323) juga menyatakan bahwa citra (image) positif yang dimiliki oleh sebuah perusahaan akan memudahkan untuk memasarkan produk atau jasanya kepada pelanggan. Dengan demikian perusahaan akan mudah mendapatkan pelanggan dan berkesempatan untuk menciptakan pelanggan yangloyal.

\subsubsection{Pengaruh Marketing Public Relation Terhadap Loyalitas Pelanggan}

Hasil penelitian menunjukkan Marketing Public Relation berpengaruh positif dan signifikan terhadap Loyalitas Pelanggan. Hal ini menunjukkan bahwa semakin baik Marketing Public Relation, semakin baik Loyalitas PelangganStudio Alam TV9 sehingga hipotesa ketiga dapat diterima. Menurut Vanessa (2007:94) Marketing public relationsmerupakan komunikasi yang dapat dipercaya untuk menjembatani perusahaan dengan konsumennya dengan tujuan menambah nilai pelanggan dan 
merangsang pembelian serta kepuasan konsumen dan sekaligus membentuk kesan terhadap perusahaan. Komunikasi dalam bentuk Marketing public relation ini antara lain bertujuan agar dapat memberikan nilai pelanggan yang superior. Nilai pelanggan itu sendiri adalah suatu perbandingan antara manfaat yang diterima dengan biaya yang dikeluarkan pelanggan. Oleh karenanya nilai pelanggan merupakan inti dari suatu hubungan dimana pemahaman dan operasi terhadap pembentukan nilai pelanggan tersebut merupakan komponen utama suatu perusahaan dalam melaksanakan hubungannya dengan pelanggan sehingga akan menghasilkan nilai pelanggan yang superior, yang merupakan kunci untuk menciptakan loyalitas pelanggan.

Marketing Public Relations jika dilakukan dengan tepat, maka akan menciptakan sebuah keloyalan konsumen dengan produk yang ditawarkan perusahaan. Konsumen sangat menentukan eksistensi suatu perusahaan, dapat dikatakan konsumen merupakan faktor maju mundurnya suatu perusahaan (Juliansyah, 2008:12). Seorang konsumen memutuskan pembelian terhadap barang atau jasa dari perusahaan tertentu berdasarkan kepercayaan yang dimiliki konsumen terhadap perusahaan yang dituju. Kepercayaan yang dimiliki konsumen tidak tumbuh dengan mudah, namun kepercayaan tumbuh melalui proses panjang yang dilakukan perusahaan khususnya marketing public relations untuk membangun brand image.

Hasil penelitian Hidayat (2015), menyatakan berdasarkan nilai koefisien determinasi diperoleh hasil bahwa loyalitas pelanggan dipengaruhi oleh peranan Marketing Public Relation. Sejalan dengan penelitian yang dilakukan Vellayati (2014) yang menyatakan bahwa Marketing Public Relations berdampak langsung terhadap Loyalitas Pelanggan.

\subsubsection{Pengaruh Marketing Public Relation Terhadap Loyalitas Pelanggan Melalui Brand Image}

Berdasarkan hasil analisis jalur tentang pengaruh tidak langsung terstandarisasi antar variabel, dimana nampak koefisien jalur dari marketing public relationsterhadap loyalitas pelanggan melalui brand image sebesar 0,266 atau 26,6 persen dengan signifikansi 0,000 . Hal ini menunjukkan bahwa marketing public relations secara tidak langsung melalui brand image berpengaruh secara positif dan signifikan terhadap loyalitas pelanggan. Apabila dibandingkan dengan pengaruh langsung marketing public relations terhadap loyalitas pelanggan yang besarnya 41,4 persen, maka pengaruh tidak langsung ini nilainya lebih kecil yaitu 26,6 persen. Hal ini mengindikasikan bahwa untuk meningkatkan pengunjung yang loyal, menajemen Studio Alam TV9 tidak harus membentuk persepsi pengunjung terhadap SATV9terlebih dahulu, tetapi bagaimana penerapan marketing public relations yang bisa meningkatkan pengunjung yang loyal.

\section{KESIMPULAN}

Dari hasil penelitian dan pembahasaan di atas, maka kesimpulan dari penelitian yang dapat diambiladalah :

(1) Marketing Public Relation berpengaruh secara signifikan terhadap Brand Imagepada Studio Alam TV9.

(2) Brand Image berpengaruh secara signifikan terhadap Loyalitas Pelangganpada Studio Alam TV9. 


\section{TMM JURNAL MAGISTER MANAJEMEN UNIVERSITAS MATARAM UNRAM VOL. 6 No. 1 MARET 2017}

(3) Marketing Public Relation berpengaruh secara signifikan terhadap Loyalitas Pelangganpada Studio Alam TV9.

(4) Disamping tiga kesimpulan yang telah disebutkan, terdapat satu temuan lainnya yaitu bahwa Marketing Public Relationsecara tidak langsung melalui brand imageberpengaruh signifikan terhadap Loyalitas Pelangganpada Studio Alam TV9.

\section{SARAN}

Adapun beberapa saran yang dapat direkomendasikan berdasarkan hasil penelitian bahwa Loyalitas Pelanggan sangatlah ditentukan oleh Marketing Public Relation dan Brand Image yang ada pada diri Pengunjung, oleh sebab itu hal-hal yang perlu diperhatikan oleh ManajemenStudio Alam TV9adalah sebagai berikut:

(1) Marketing Public Relation dalam suatu organisasi sangat penting untuk diperhatikan manajemen. Marketing Public Relation mempunyai pengaruh langsung terhadap Brand Image. Ada beberapa indikator Marketing Public Relation yang perlu ditingkatkan oleh manajemen Studio Alam TV9 diantaranya mengemas setiap event agar terlihat lebih menarik. Selain itu, penyampaian berita melalui TV9 dapat dilakukan dengan memilih sesuatu yang dianggap paling menarik dan unik dari Studio Alam TV9. Senantiasa berinovasi untuk menciptakan produk baru atau wahana baruyang memiliki kriteriaamandanmenyenangkan sehingga Loyalitas Pelangganpengunjung menjadi semakin tinggi dimasa yang akan datang.

(2) Bagi para peneliti yang tertarik dengan judul yang sama dengan kajian pengaruh langsung dan tidak langsung menggunakan analisis jalur, sebaiknya memperhatikan hal-hal seperti,menambah variabel-variabel lain yang mempunyai keterkaitan dengan LoyalitasPelanggan. Disamping itu untuk penelitian selanjutnya disarankan menggunakan metoda kualitatif, agar dapat menggali segala permasalahan dengan lebih mendalam yang mungkin saja tidak terungkap dengan penelitian kuantitatif.

\section{DAFTAR PUSTAKA}

Ruslan Rosady, 2010. MetodePenelitian Public Relations danKomunikasi. Jakarta: PT. Raja GrafindoPersada.

Riduan and Kuncoro, 2007. Cara MenggunakandanMemakaiAnalisisJalur (Path Analysis). Bandung:Alfabeta

Kotler and Lee, 2007. Pemasaran Di SektorPublik. Jakarta: PT. Indeks.

KuncoroMudrajad, 2007. MetodeKuantitatif. Yogyakarta: UPP STIM YKPN.

Kotler and Keller, 2009. ManajemenPemasaran, EdisiKetigaBelas. Jakarta:Erlangga.

Fandy, Gregorius and Dady, 2008. PemasaranStrategik. ANDI: Yogyakarta.

Ardianto, Elvinaro. 2008. Public Relations Praktis. Bandung: WidyaPadjajaran.

Sutisna, 2001. PerilakuKonsumendanKomunikasiPemasaran. Bandung: PT RemajaRosdakarya.

Rangkuti, Freddy. 2008. The Power of Brand: TeknikMengelola Brand Equity danStrategiPengembanganMerek. Jakarta: Ghalia Indonesia. 


\section{TMM JURNAL MAGISTER MANAJEMEN UNIVERSITAS MATARAM UNRAM VOL. 6 No. 1 MARET 2017}

Arikunto.S., 2005, ProsedurPenelitianSuatuPendekatanPraktik. PT. RinekaCipta. Jakarta.

Sugiyono., 2003, 'MetodePenelitianKuantitatifKualitatifdan RED', PenerbitAlfabeta. Bandung 2012' 'MetodePenelitianKuantitatifKualitatifdan $R \mathcal{E} D^{\prime}$, PenerbitAlfabeta. Bandung

Hurriyati, Ratih. 2010. Bauranpemasarandanloyalitaskonsumen. Bandung: Alfabeta.

Jefkins, Frank dan Daniel Yadin. 2004. Publicrelations. Alihbahasa : HarisMunandar.Jakarta: Erlangga.

Kotler, Phillip, SweeHoo Ang, Meng Siew Leong and Chin Tiong Tan. 1996. Marketingmanagement: an asian perspective.Singapore: Prentice Hall.

Kotler, Phillip and Kevin Lane Keller. 2009.Manajemen pemasaran. Jilid 1.

Edisiketigabelas. Jakarta: PenerbitErlangga.

Ruslan, Rosady. 2006. Manajemen public relationsdan media komunikasi: Konsepsidanaplikasi. Jakarta: Raja GrafindoPersada.

Kasali, Rhenald, 2005, Manajemen Public Re-lations: KonsepdanAplikasinya di In-donesia, PustakaUtamaGrafiti.

Ruslan, Rosady, 2006, Manajemen Public Re-lationsdan Media Komunikasi : KonsepsidanAplikasi, Raja GrafindoPersada, Jakarta.

Sulaksana, Uyung, 2007, Integrated MarketingCommunications TeksdanKasus,PustakaPelajar, Yogyakarta.

Sumarwan, Ujang, 2004, PerilakuKonsumenTeori Dan PenerapannyaDalamPemasaran, Ghalia Indonesia, Bogor.

Alifahmi, Hifni. 2008. Marketing Communication Orchestra. CetakanPertama. Jakarta: Sygma.

Ardianto,Elvinaro.2008.PublicRelationsPraktis.Bandung: WidyaPadjajaran.

Gaffar, Vanessa. 2007. CRM dan MPR Hotel (Customer Relationship Management and Marketing Public Relations). Bandung: Alfabeta.

Griffin, Jill. 2005. Customer Loyalty: MenumbuhkandanMempertahankanKesetiaanPelanggan. Alih Bahasa: Dr. DwiKartini Yahya. Jakarta: PenerbitErlangga

Hurriyati, Ratih. 2008. BauranPemasarandanLoyalitasKonsumen. Ed.2 Bandung: Alfabeta.

Kasali, Rhenald. 1999. ManajemenPublikRelasi: konsepdanaplikasiya di Indonesia. Cetakankedua. Jakarta: PustakaUtamaGrafiti.

Kotler, Philip and Keller, Kevin Lane. 2006. Marketing Management. Twelfh Edition. New Jersey: Prentice Hall. 2008.Prinsip-PrinsipPemasaran,Edisike-

12. Alih Bahasa: Bob Sabran. Jakarta: PenerbitErlangga. 


\section{TMM JURNAL MAGISTER MANAJEMEN UNIVERSITAS MATARAM UNRAM VOL. 6 No. 1 MARET 2017}

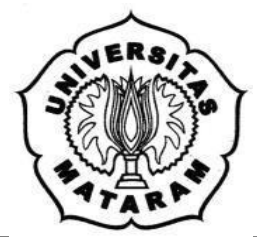

Maholtra,N.K.2009.RisetPemasaranPendekatanTerapan. Alih Bahasa: Damas Sihombing. Jilid 1. Jakarta:Indeks.

Malik, Fozia, et al. 2012. The Impact of Price Perception, Service Quality, and Brand Image on Customer Loyalty (Study of Hospitality Industry in Pakistan). Interdisciplinary Journal of Contemporary Research in Business. 4(5) : 487505

Mardalis, Ahmad. 2005. MeraihLoyalitasPelanggan. Jakarta: BalaiPustaka.

Soemirat, SolehdanElvinaroArdianto. 2008. Dasar-Dasar Public Relations. Bandung: PT RemajaRosdakarya.

Surachman, 2008. Dasar-DasarManajemenMerek. Malang: BanyuMedia Publishing. 